\title{
DROUGHT RESISTANCE OF SUGAR-CANE CROP FOR DIFFERENT LEVELS OF WATER AVAILABILITY IN THE SOIL
}

\section{FERNANDO DA S. BARBOSA ${ }^{1}$, RUBENS D. COELHO ${ }^{2}$, RAFAEL MASCHIO ${ }^{3}$, CARLOS $^{2}$ J. G. DE S. LIMA ${ }^{4}$, EVERALDO M. DA SILVA ${ }^{5}$}

\begin{abstract}
Soil water availability is the main cause of reduced productivity, and the early development period most sensitive to water deficit. This study aimed to evaluate the drought resistance of the varieties of sugar-cane RB867515 and SP81-3250 during the early development using different levels of water deficit on four soil depths. The experiment was conducted at the Department of Biosystems at Escola Superior de Agricultura "Luiz de Queiroz" (ESALQ/USP) in a greenhouse in soil classified as Oxisol, sandy loam texture (Series "Sertãozinho"). Once exhausted the level of available water in the soil, the dry strength of the studied strains are relatively low. Water balance with values less than $-13 \mathrm{~mm}$ cause a significant decrease in the final population of plants, regardless of the variety, and values below $-35 \mathrm{~mm}$, leads to the death of all plants.
\end{abstract}

KEYWORDS: irrigation, plant population, Saccharum spp., drought tolerance.

\section{RESISTÊNCIA À SECA EM CANA-DE-AÇÚCAR PARA DIFERENTES NÍVEIS DE DISPONIBILIDADE HÍDRICA NO SOLO}

RESUMO: A disponibilidade hídrica é a principal causa da redução da produtividade, sendo o início do desenvolvimento o período mais sensível ao déficit hídrico. O presente trabalho teve como objetivo avaliar a resistência à seca das variedades de cana-de-açúcar RB867515 e SP81-3250 durante o início do desenvolvimento, utilizando diferentes níveis de déficit hídrico, em quatro profundidades de solo. O experimento foi realizado no Departamento de Engenharia de Biossistemas da Escola Superior de Agricultura "Luiz de Queiroz” (ESALQ/USP), em estufa, em solo classificado como Latossolo Vermelho-Amarelo, textura francoarenosa (Série "Sertãozinho”). Uma vez esgotado o nível de água disponível do solo, a resistência à seca das variedades estudadas é relativamente baixa. Balanços hídricos com valores menores que $-13 \mathrm{~mm}$ causam queda significativa na população final de plantas, independentemente da variedade, e valores abaixo de $35 \mathrm{~mm}$, levam à morte $\mathrm{o}$ total de plantas.

PALAVRAS-CHAVE: irrigação, população de plantas, Saccharum spp., tolerância à seca.

\section{INTRODUCTION}

The sugar-cane (Saccharum spp.) is a crop of great social, economic and environmental importance to Brazil, occupying 7.1 million hectares, with production of approximately 570 million tons. The State of São Paulo stands out with the largest area and highest production in the country, 3.8 million hectares and 343 million tons respectively (AGRIANUAL, 2010). According to the Institute of Agricultural Economics - IEA (2012), the perspective is that there is an increase in cultivated area. For the harvest of 2015/2016, is estimated 12.2 million hectares with production of 902.8 million tons. Brazil is emerging as a world leader in exports of sugar and the use of sugar-

\footnotetext{
${ }^{1}$ Eng ${ }^{\circ}$ Agrônomo, Doutorando, Departamento de Engenharia de Biossistemas, USP/Piracicaba - SP, fernandosb@usp.br.

${ }^{2}$ Eng $^{\circ}$ Agrônomo, Prof. Associado (N3), Departamento de Engenharia de Biossistemas, USP/Piracicaba - SP, rdcoelho@usp.br.

${ }^{3}$ Eng $^{\circ}$ Agrônomo, Doutorando, Departamento de Engenharia de Biossistemas, USP/Piracicaba - SP, rafaelmaschio@usp.br.

${ }^{4}$ Eng $^{\circ}$ Agrônomo, Prof. Doutor, Departamento de Engenharia Agrícola e Solos, UFPI/Teresina - PI, carloslima@ufpi.edu.br.

${ }^{5}$ Eng ${ }^{\circ}$ Agrônomo, Prof. Doutor, Departamento de Engenharia Agrícola e Solos, UFPI/Bom Jesus - PI, everaldo@ufpi.edu.br.

Recebido pelo Conselho Editorial em: 25-3-2011

Aprovado pelo Conselho Editorial em: 24-5-2013
} 
cane as source of renewable energy, primarily by increasing participation of flex-fuel vehicles in the Brazilian automotive fleet (COSTA et al., 2011).

Plants are subject to variety of environmental stresses, including inadequate temperatures, physic-chemical conditions of unfavorable soil and various diseases and pests. However, water is a limiting factor affecting plant growth, development and yield, especially in arid and semi-arid regions, where plants are often exposed to water shortages, also known as water stress (EFEOĞLU et.al., 2009).For sugar-cane, high temperature provides increasing evapotranspiration in plants well supplied with water, but in plants under water deficit causes reduction in leaf area, growth of tillers and stimulates senescence of leaves (INMAN-BAMBER, 2004).

Information on water demand for sugar cane is varied in the literature. According INMANBAMBER \& SMITH (2005), culture requires between 1,500 and 2,500 mm per season and irrigation management should be done according to the phenological stages of each variety. Being the crop cycle divided into four phenological stages: sprouting and emergence; tillering stage, stalk growth and maturation of the stems. For sugar cane, the early development is the most sensitive period to water deficit (ROSENFELD \& LEME, 1984).

The sugar cane has the characteristic to be a crop with high technology applied to the production system, as high dosages of fertilizer; biological and chemical control of diseases and weeds; control soil compaction with the use of high-flotation tires; improved varieties; use of maturing, among others (DALRI \& CRUZ, 2008). However, SMITH \& SINGLES (2006) as well as CARR \& KNOX (2011) state that more research is needed to clearly understand the mechanisms of crop response to water stress. Thus, the study aimed to evaluate the drought resistance of the varieties of sugar-cane RB867515 and SP81-3250 during the early development using different levels of water deficit to four depths of soil.

\section{MATERIALS AND METHODS}

The experiment was conducted at the Department of Engineering Biosystems at Escola Superior de Agricultura "Luiz de Queiroz" (ESALQ / USP), in greenhouse located in Piracicaba$\mathrm{SP}$, at latitude $22^{\circ} 42^{\prime} 32^{\prime \prime} \mathrm{S}$, longitude $47^{\circ} 37^{\prime} 45^{\prime \prime} \mathrm{W}$ and altitude of $548 \mathrm{~m}$. The climate in the Köeppen climate classification, is Cwa, that is, humid subtropical, with three driest months (June, July and August), characterized by rainfall in the summer and dry in the winter.

The treatments consisted of the combination of two varieties of sugar-cane, RB867515 (V1) and SP81-3250 (V2), four soil depths and four levels of water deficit, represented by cumulative reference evapotranspiration (EToAc) until the treatment be irrigated again with sufficient irrigation depth capacity to raise the soil moisture to field capacity. The randomized block factorial $2 \times 4 \times 4$ was used, totaling 32 treatments arranged in bands. In an area of $160 \mathrm{~m}^{2}$, were distributed 96 cement boxes of $100 \mathrm{~L}$, with dimensions of $0.60 \times 0.40 \times 0.45 \mathrm{~m}$, divided into four bands spaced $0.80 \mathrm{~m}$ between rows and $0.50 \mathrm{~m}$ between boxes, maintaining a distance of $1.00 \mathrm{~m}$ from the sides of the greenhouse. . The boxes were filled with different layers of stone, crushed stone $\mathrm{n}^{0} 02$ and soil, comprising layers of 40; 30; 20 and $10 \mathrm{~cm}$ of soil, designated S40, S30, S20 and S10, respectively. Bidim mat was used for separating layer of stones and soil. With data from physical and hydro characterization of soil, water availability were determined for the four soil depths, being the available water capacity (AWC) 12.11; 24.92; 37.73 and $48.61 \mathrm{~mm}$ for S10, S20, S30 and S40, respectively, were calculated adding up the AWC layers that make up each treatment (Table 1).

It was used a drip irrigation with emitters button type (PCJ-CNL), making the irrigation independent for each treatment through 32 valves sphere, where the opening of each valve empowered the irrigation in three boxes. The coefficient of uniformity Christiansen (CUC) was over $90 \%$ for this system.

The meteorological variables monitored were solar radiation, relative humidity and air temperature by pyranometer (LP02-L12 - Campbell Sci) and Vaisala sensor (HMP45C-L12 - 
Campbell Sci), respectively. The sensors were installed at $2.0 \mathrm{~m}$ height in the center of the greenhouse, and with the daily weather data was calculated the reference evapotranspiration $\left(\mathrm{mm} \mathrm{day}^{-1}\right.$ ) by the standard method proposed by FAO (Penman-Monteith ETo). Following the standardization of FAO the wind speed was considered $0.5 \mathrm{~m} \mathrm{~s}^{-1}$ to improve the estimative for the low wind conditions, as in the case of inside the greenhouse.

The soil was classified as Oxisol, sandy loam texture, called "Sertãozinho" Series.The hydrophysical soil characteristics are presented in Table 1. The Greenhouse had coverage of transparent polyethylene film, $150 \mu \mathrm{m}$ thick and sides closed by type screen shading with 30\% interception.

TABLE 1. Physical-water soil parameters.

\begin{tabular}{|c|c|c|c|c|c|c|c|c|c|}
\hline \multirow{3}{*}{ Layer $(\mathrm{cm})$} & \multirow{2}{*}{ CC } & \multirow{2}{*}{ PMP } & \multirow{3}{*}{$\begin{array}{l}\text { AWC } \\
(\mathrm{mm})\end{array}$} & \multirow{2}{*}{$\mathrm{D}_{\mathrm{s}}$} & \multirow{2}{*}{$\mathrm{D}_{\mathrm{p}}$} & \multirow{3}{*}{$\begin{array}{l}\text { PT } \\
\text { (\%) }\end{array}$} & \multicolumn{3}{|c|}{ Granulometric Fractions } \\
\hline & & & & & & & Sand & Silt & Clay \\
\hline & \multicolumn{2}{|c|}{$\mathrm{g} \mathrm{g}^{-1}$} & & \multicolumn{2}{|c|}{$\mathrm{g} \mathrm{cm}^{-3}$} & & \multicolumn{3}{|c|}{$\%$} \\
\hline $0-10$ & 0.148 & 0.069 & 12.11 & 1.53 & 2.65 & 42.3 & 75.1 & 7.8 & 17.1 \\
\hline $10-20$ & 0.151 & 0.065 & 12.81 & 1.50 & 2.65 & 43.4 & 74.5 & 8.0 & 17.5 \\
\hline $20-30$ & 0.151 & 0.065 & 12.81 & 1.50 & 2.65 & 43.4 & 74.5 & 8.0 & 17.5 \\
\hline $30-40$ & 0.143 & 0.078 & 10.88 & 1.69 & 2.64 & 36.0 & 74.4 & 8.6 & 17.0 \\
\hline
\end{tabular}

CC: moisture at field capacity (corresponding to the matrix potential $(\psi \mathrm{m})$ of $4.85 \mathrm{kPa})$. PMP: moisture in the permanent wilting point (corresponding to the matrix potential $(\psi \mathrm{m})$ of $1500 \mathrm{kPa})$. AWC: available water capacity. Ds: density. Dp: particle density of the soil. PT: Total soil porosity.

Plants were obtained by mini planting cuttings (03-30-2010), initially in trays of 32 cells containing commercial substrate (Basaplant $\left.{ }^{\circledR}\right)$, in each cell $\left(190 \mathrm{~cm}^{3}\right.$ ) put up with just one bud. During the period in which the plants were growing in trays was performed daily irrigations sufficient for the substrate to be maintained with moisture close to field capacity (approximately $5 \mathrm{~mm} \mathrm{day}^{-1}$ ). The transplant occurred at 32 days after planting (DAP), thus starting tillering and formation of tussocks for evaluation after transplanting boxes were opened. The transplant occurred at 32 days after planting (DAP), thus starting tillering and formation of tussocks for evaluation after transplanting in the boxes. Four "holes" were opened in the soil for each box, with a depth of 8 to $10 \mathrm{~cm}$, where the cuttings were placed with the root system further involved by substrate. In order to reduce the presence of weeds and to minimize the evaporation of water in the soil, after transplantation, was placed a layer of sugar-cane straw on the surface of the soil in all boxes, simulating a condition on mechanized harvesting field $\left(19 \mathrm{tha}^{-1}\right)$.

From transplanting, irrigation management was performed based on data from soil moisture obtained from Tensiometers of porous capsule readings. The humidity was calculated using the van Genuchten model using the empirical parameters (Table 2) and average readings of matric potential $\left(\psi_{\mathrm{m}}\right)$ of each treatment, where the need for irrigation was calculated to elevate the soil moisture capacity field.

The management methodology presented was initially adopted for all treatments, always keeping the $\psi_{\mathrm{m}}$ above $-25 \mathrm{kPa}$. For different levels of water deficit $(\mathrm{N})$ was performed irrigation of all parcels until 07/01/2010 (93 DAP), increasing the moisture of field capacity, and to this day has been suspended the management in the treatments N2, N3 and N4 over the periods presented in Table 3. These periods were adopted in an attempt to visually survive all treatment plans N1; plants of S20, S30 and S40 treatments in N2; plants of S30 and S40 treatments in N3 and treatment plans S40 in N4. 
TABLE 2. Saturation humidity $\left(\theta_{\mathrm{s}}\right)$ and residual $\left(\theta_{\mathrm{r}}\right)$ values and the empirical parameters $(\alpha, \mathrm{n}$ e $\mathrm{m})$ the model of GENUCHTEN (1980).

\begin{tabular}{cccccc}
\hline layer $(\mathrm{cm})$ & $\theta_{\mathrm{s}}\left(\mathrm{m}^{3} \mathrm{~m}^{-3}\right)$ & $\theta_{\mathrm{r}}\left(\mathrm{m}^{3} \mathrm{~m}^{-3}\right)$ & $\alpha\left(\mathrm{kPa}^{-1}\right)$ & $\mathrm{m}$ & $\mathrm{n}$ \\
\hline $0-10$ & 0.421 & 0.098 & 1.3464 & 0.1799 & 2.7175 \\
$10-20$ & 0.412 & 0.085 & 1.5708 & 0.1648 & 2.5028 \\
$20-30$ & 0.412 & 0.085 & 1.5708 & 0.1648 & 2.5028 \\
$30-40$ & 0.374 & 0.122 & 1.1291 & 0.2749 & 1.5619 \\
\hline
\end{tabular}

TABLE 3. Description of the treatments of water deficit levels.

\begin{tabular}{ccccc}
\hline Treatment & $\begin{array}{c}\text { Starting Date of the } \\
\text { Management }\end{array}$ & DAP & $\begin{array}{c}\text { Days Without } \\
\text { Management }\end{array}$ & EToAc (mm) \\
\hline N1 & $07 / 02 / 2010$ & 94 & - & - \\
N2 & $07 / 15 / 2010$ & 107 & 14 & 21 \\
N3 & $07 / 23 / 2010$ & 115 & 22 & 38 \\
N4 & $02 / 08 / 2010$ & 125 & 32 & 58 \\
\hline
\end{tabular}

DAP: days after planting; EToAc: reference evapotranspiration accumulated.

For N4 treatment before resuming the initial handling, yet with minimal moisture in the soil resulting from $58 \mathrm{~mm}$ of EToAc, soil samples were taken for measurement of moisture by the gravimetric method, since N2, N3 and N4 reached levels smaller than $-90 \mathrm{kPa}$ matric potential $\left(\psi_{\mathrm{m}}\right)$, not being possible to be measured by densitometry.

In the analysis of plant survival was evaluated the percentage of living tussocks to 136 DAP in each plot, when all treatments were again handled with soil moisture close to field capacity for at least 11 days. Criterion was adopted as a visual analysis, and the tussocks that did not have any green leaf, even the cartridge leaves, both the tiller as the primary stem and no issuance of new tillers were considered dead tussocks. So the parcels which have $0 ; 1 ; 2 ; 3$ and 4 were evaluated as dead tussocks, respectively 100; 75; 50; 25 and $0 \%$ as live tussocks.

In the intention to facilitate understanding of the results, the climatic water balance (BH) was calculated using the concept of water balance (THORNTHWAITE \& MATHER, 1955), considering the soil as a fixed reservoir, where the water slide stored until maximum field capacity is lost by evapotranspiration and replenished by rainfall or irrigation. Assuming that all treatments started with initial moisture content in the field capacity, that is the initial irrigation depth is equal to AWC and that the period in which they were being imposed treatments on the deficit of water level reversal that there were no replacements in the system, balances were estimated by eq. (1).

$$
\mathrm{BH}_{\mathrm{S}_{\mathrm{i}} \mathrm{N}_{\mathrm{i}}}=\mathrm{AWC}_{\mathrm{S}_{\mathrm{i}}}-\mathrm{EToAc}_{\mathrm{N}_{\mathrm{i}}}
$$

where,

$\mathrm{BH}_{\mathrm{SiNi}}$ - water balance for the treatment of soil $\mathrm{S}_{\mathrm{i}}$ and level of water deficit $\mathrm{N}_{\mathrm{i}}, \mathrm{mm}$;

$\mathrm{AWC}_{\mathrm{Si}}$ - the total available water capacity to soil treatment $\mathrm{S}_{\mathrm{i}}$, mm, and

$\mathrm{EToAc}_{\mathrm{Ni}}$ - accumulated reference evapotranspiration for treatment $\mathrm{N}_{\mathrm{i}}, \mathrm{mm}$.

As the percentage values of living tussocks related with $\mathrm{BH}$ follow a sigmoid distribution, the adjustment equation [eq.(2)] was determined to estimate the percentage of live tussocks due to the water balance using the Table Curve $2 \mathrm{D}^{\circledR}$ software. The equation estimates adjusted values within the minimum limit of $0 \%$ of live plants to a maximum of $100 \%$.

$$
\operatorname{TV}(\%)=a+\frac{b}{1+e^{-\left(\frac{B H-c}{d}\right)}}
$$


where,
a - 1.129029596;
b - 98.23998897;
c - -18.021391;
d - 3.683549003;
TV - amount of living tussocks, \%, and
$\mathrm{BH}$ - water balance of the period, mm.

\section{RESULTS AND DISCUSSION}

Comparing the moisture on the maximum level of water deficit (08/02/2010) with the measure following the days after irrigation (08/05/2010) (Table 4), it is clear that, regardless of the depth, soil moisture reached average values below the wilting point when on maximum deficit, that is, water deficit imposed for the treatment N4 was very severe. However, the humidity returned to near average values at field capacity after restarting the management been necessary a later discussion concerning the duration of the water deficit.

BONATO (2007) states that plant responses to stress depend on the duration, severity, the number of exposures and the combination of stressors as well as the type of organ and tissue developmental age and genotype. Some responses enable plants to be acclimate to stress, while others are not apparent acclimated.

TABLE 4. Average values of gravimetric soil moisture $\left(\mathrm{g} \mathrm{g}^{-1}\right)$ for the dates of maximum deficit (08/02/2010) and after returning to the handling (08/05/2010) for the different soil depths for both varieties in treatment N4.

\begin{tabular}{cccccc}
\hline \multirow{2}{*}{ Treatment } & \multicolumn{2}{c}{ RB867515 } & & \multicolumn{2}{c}{ SP81-3250 } \\
& $08 / 02 / 2010$ & $08 / 05 / 2010$ & & $08 / 02 / 2010$ & $08 / 05 / 2010$ \\
\cline { 1 - 2 } S10 & 0.043 & 0.144 & & 0.040 & 0.145 \\
S20 & 0.047 & 0.140 & & 0.053 & 0.154 \\
S30 & 0.050 & 0.147 & & 0.056 & 0.156 \\
S40 & 0.046 & 0.156 & & 0.053 & 0.158 \\
\hline Average & 0.047 & 0.147 & & 0.051 & 0.153 \\
\hline
\end{tabular}

For treatment N1 was not accounted buildup ETo since the beginning of the day 07/02/2010 (94 DAP) irrigation management has been performed again for this treatment. During the period 94 to107 DAP (N2), both temperature and radiation remained with the lowest values among treatments averaging $19.4^{\circ} \mathrm{C}$ and $7.8 \mathrm{MJ} \mathrm{m}^{-2}$ day $^{-1}$, resulting in ETo average of $1.6 \mathrm{~mm}^{-1}{ }^{-1}$. From $109 \mathrm{DAP}$, the highest values of temperature, radiation and consequently the ETo in the period, raising the average ETo from N3 (94 to 115 DAP) and N4 (94 to 125 DAP) to 1.7 and $1.8 \mathrm{~mm} \mathrm{day}^{-1}$ respectively.

The result of the live tussocks is the most robust indicator for the estimated plant population per unit of cultivated area (Table 5). In the variance analysis for the percentage of live tussocks in each soil treatment the level of water deficit $(\mathrm{N})$ caused significantly different response to the S10, S20 and S30 treatments at a 1\% level of probability. There was no difference between varieties, or interaction between $\mathrm{N}$ and varieties was observed. For the treatment $\mathrm{S} 40$, the levels of water deficit did not result in significant reduction in percentage of live tussocks. 
TABLE 5. Summary of analysis of variance for the percentage of clumps of living varieties RB867515 (V1) and SP81-3250 (V2) as a function of EToAc for the four soil depths.

\begin{tabular}{|c|c|c|c|c|c|}
\hline \multirow{2}{*}{ FV } & \multicolumn{5}{|c|}{ Statistic F } \\
\hline & GL & S10 & S20 & S30 & $\mathrm{S} 40$ \\
\hline$\overline{\mathrm{N}}$ & 3 & $228.20^{* *}$ & $152.88 * *$ & $10.86 * *$ & $2.19^{\mathrm{ns}}$ \\
\hline Variety & 1 & $1.40^{\mathrm{ns}}$ & $0.30^{\mathrm{ns}}$ & $0.00^{\mathrm{ns}}$ & $0.24^{\mathrm{ns}}$ \\
\hline $\mathrm{N} x$ Variety & 3 & $0.47^{\mathrm{ns}}$ & $0.30^{\mathrm{ns}}$ & $0.00^{\mathrm{ns}}$ & $0.24^{\mathrm{ns}}$ \\
\hline Block & 2 & $1.40^{\mathrm{ns}}$ & $0.30^{\mathrm{ns}}$ & $0.81^{\mathrm{ns}}$ & $1.28^{\mathrm{ns}}$ \\
\hline$\overline{\mathrm{CV}(\%)}$ & & 16.56 & 12.51 & 29.73 & 22.06 \\
\hline General average & & $52.08 \mathrm{~B}$ & $73.96 \mathrm{AB}$ & 83.33 A & $93.75 \mathrm{~A}$ \\
\hline Average V1 & & 50.00 & 72.92 & 83.33 & 91.67 \\
\hline Average V2 & & 54.17 & 75.00 & 83.33 & 95.83 \\
\hline
\end{tabular}

* e **: Significant at 5\% and 1\% probability, respectively. ${ }^{\text {ns }}$ : not significant. Averages followed by the same letter in rows do not differ by Tukey test at the 0.05 level of probability. S10: 0-10 cm soil layer; S20: 0-20 cm soil layer; S30: 0-30 cm soil layer; S40: 0$40 \mathrm{~cm}$ soil layer.

The water balance affects the percentage of live tussocks significantly at $1 \%$ level of probability. The interaction between varieties with $\mathrm{BH}$ did not significantly affect the percentage of living tussocks. The RB867515 showed an average of $74.48 \%$ of living tussocks, which did not differ significantly from the average of $77.08 \%$, obtained by SP81-3250.

In Table 6 it is evident that both varieties and all combinations with null or positive $\mathrm{BH}$, plant population remained $100 \%$ alive, even through periods without irrigation. For BH negative values up to $13 \mathrm{~mm}$, there was no significant difference in the percentage of live tussocks, compared to the values of BH zero or positive. Combinations S10 N2 and S40 N4 worth a separate discussion, referring to the discussion about the duration of the water deficit, as both result in the same $\mathrm{BH}$ (-9.0 $\mathrm{mm}$ ) maintain maximum plant population, but for different reasons. These are the extreme depth treatments (S10:10cm and S40:40cm) combined with lower and longer time drought.

TABLE 6. Average amount of tussocks alive (\%) for RB867515 (V1), SP81-3250 (V2), average agreement with the climatic water balance (BH).

\begin{tabular}{|c|c|c|c|c|c|}
\hline \multicolumn{2}{|c|}{ Treatment } & $\mathrm{BH}$ & RB867515 & SP81-3250 & Average \\
\hline Soil (S) & EToAc (N) & $(\mathrm{mm})$ & \multicolumn{3}{|c|}{ live tussocks (\%) } \\
\hline S10 & N4 & -46 & $0.0 \mathrm{Ac}^{(1)}$ & $0.0 \mathrm{Ab}$ & $0.0 \mathrm{~b}$ \\
\hline S20 & N4 & -33 & $0.0 \mathrm{Ac}$ & $8.3 \mathrm{Ab}$ & $4.2 \mathrm{~b}$ \\
\hline S10 & N3 & -26 & 8.3 Ac & 16.7 Ab & $12.5 \mathrm{~b}$ \\
\hline S30 & N4 & -20 & $33.3 \mathrm{Abc}$ & $33.3 \mathrm{Ab}$ & $33.3 \mathrm{~b}$ \\
\hline S20 & N3 & -13 & 91.7 Аа & 91.7 Aa & $91.7 \mathrm{a}$ \\
\hline S10 & N2 & -9 & $91.7 \mathrm{Aa}$ & $100 \mathrm{Aa}$ & 95.8 a \\
\hline S40 & N4 & -9 & 66.7 Aab & 83.3 Aa & 75.0 a \\
\hline S30 & N3 & 0 & 100.0 Aa & $100.0 \mathrm{Aa}$ & $100.0 \mathrm{a}$ \\
\hline S20 & N2 & 4 & 100.0 Aa & 100.0 Aa & $100.0 \mathrm{a}$ \\
\hline S40 & N2 & 11 & 100.0 Aa & 100.0 Aa & $100.0 \mathrm{a}$ \\
\hline S10 & N1 & 12 & $100.0 \mathrm{Aa}$ & 100.0 Аа & $100.0 \mathrm{a}$ \\
\hline S30 & N2 & 17 & 100.0 Aa & 100.0 Аa & $100.0 \mathrm{a}$ \\
\hline S20 & N1 & 25 & 100.0 Aa & $100.0 \mathrm{Aa}$ & $100.0 \mathrm{a}$ \\
\hline S40 & N3 & 28 & 100.0 Аа & $100.0 \mathrm{Aa}$ & $100.0 \mathrm{a}$ \\
\hline S30 & N1 & 38 & 100.0 Aa & $100.0 \mathrm{Aa}$ & $100.0 \mathrm{a}$ \\
\hline $\mathrm{S} 40$ & N1 & 49 & $100.0 \mathrm{Aa}$ & $100.0 \mathrm{Aa}$ & $100.0 \mathrm{a}$ \\
\hline
\end{tabular}

(1) Means followed by the same lowercase do not differ on the vertical and with uppercase letters horizontally by Tukey test at $5 \%$ probability

In the case of the combination S40 N4, the plants had a long period without irrigation (32 days) in the last four days before the maximum deficit (121 to 124 DAP), the average ETo was $2.2 \mathrm{~mm} \mathrm{day}^{-1}$, been two of the three days of maximum ETo $\left(2.3 \mathrm{~mm}^{-1 a y}{ }^{-1}\right)$ also occurred during this period, but the AWC of the soil up to $40 \mathrm{~cm}(48.61 \mathrm{~mm})$ was sufficient for the plant to adapt to the condition of low water availability. Even through this critical final period the plants did not actually 
die, because there were almost 20 days until the EToAc approached to the value of AWC, with a negative balance for only 5 days.

MACHADO et al. (2009) discuss the importance of speed in which the reduction of water availability occurs in the soil; stating that in slower speed can make the plant acclimation to limiting condition. For IAC SP 94-2094, the authors noted evidence of physiological acclimation when the maximum deficit occurred after 43 days of withholding irrigation, showing no reduction in leaf water potential, the apparent carboxylation efficiency and intrinsic water use efficiency with $\mathrm{CO}_{2}$ assimilation less affected in the initial growth phase, compared to the phase in which the maximum deficit was close to 15 days, that is, only 1/3 of the time previously mentioned.

For S10 N2 in 7 days the EToAc already equaled to AWC, little time for the plant to adapt to the condition of water restriction, but $\mathrm{BH}$ remained negative for only 5 days. Thus, with the average ETo the low period (average $1.6 \mathrm{~mm} \mathrm{day}^{-1}$ ), reaching a maximum of $1.8 \mathrm{~mm}$ day $^{-1}$, and irrigation resumed soon, the plant did not acclimatize, however, the time it went under water restriction was not sufficient to cause the death of tussocks.

It should be emphasized that not only the "raw" results of the water balance should be considered for future studies of drought resistance among varieties at different stages, but also the speed of imposition to the water deficit within the limits studied here to $\mathrm{BH}$, identifying a mechanism for hardening of the plant to this kind of stress.

In Figure 1, the percentage values of living tussocks relating to $\mathrm{BH}$ has a sigmoid distribution ( $\mathrm{r}^{2}$ close to 0.97 ), and for the range of -30.0 to $-10.0 \mathrm{~mm}$ the $\mathrm{BH}$ percentage values of living tussocks change abruptly, with values of $4.7 \%$ of living tussocks for $-30.0 \mathrm{~mm}$ and $89.4 \%$ to $10.0 \mathrm{~mm}$, with a critical track that should be studied in more detail in next experiments.

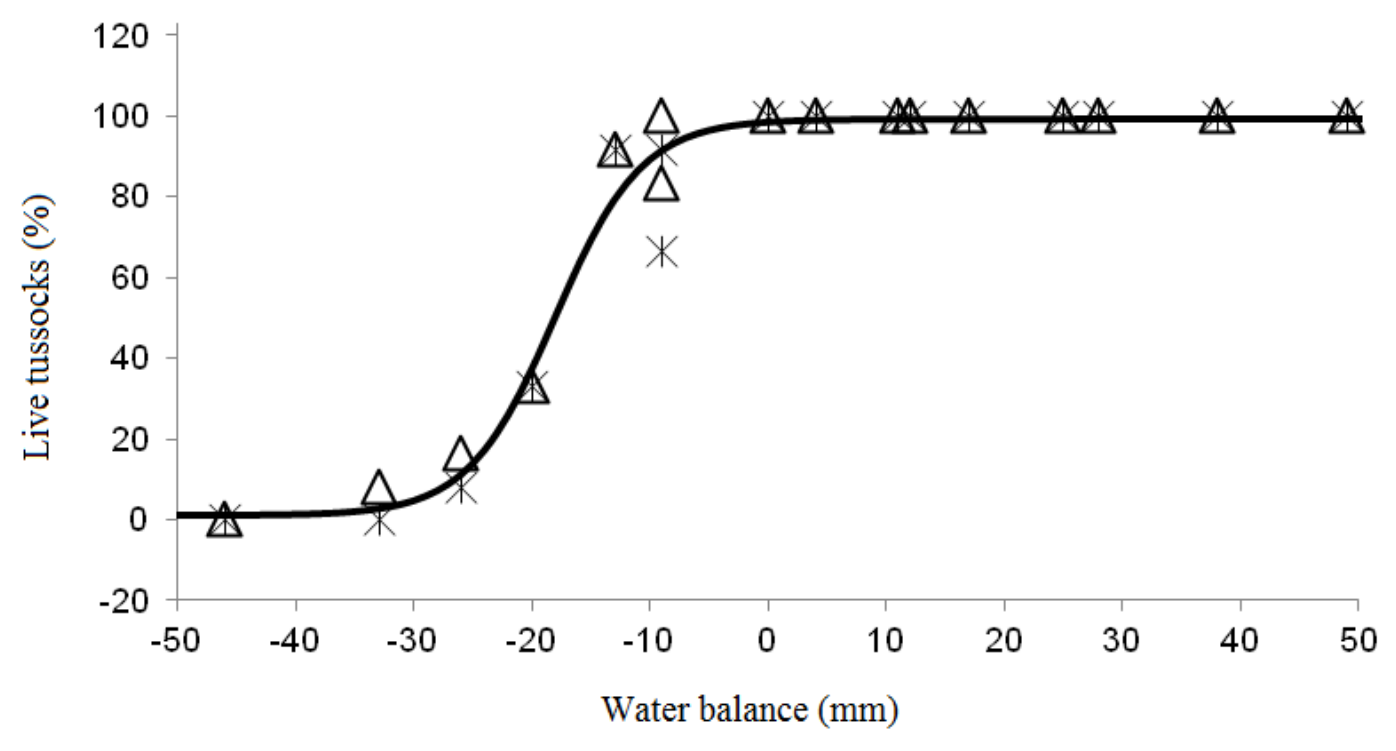

\section{* RB $867515 \quad \Delta$ SP 81-3250}

FIGURE 1. Graphical representation of the adjustment equation between the quantity of living tussocks and water balance for both varieties.

So once the level of available water in the soil is exhausted, the drought tolerance of the varieties under study is relatively low. Water balance with values lower than $-13 \mathrm{~mm}$ caused a significant decrease in plant population, regardless of the variety and from a cumulative value of $-35 \mathrm{~mm}$, no plants survived. The effective mechanisms of drought resistance by the sugar-cane crop should be correlated with the ability of plants to prevent excessive loss of water to the atmosphere (stomata regulation, resistance to flow in the xylem, root contraction etc.) or more effective 
exploitation of the available water in the soil (root depth), as to "prevent" dry and not necessarily "resist" to it.

\section{CONCLUSIONS}

The response to water deficit to RB867515 and SP81-3250 sugar-cane varieties do not differ regardless of soil water availability.

The drought resistance for SP81-3250 and RB867515 varieties is predicted with good accuracy, based on water availability of the soil and potential evapotranspiration of accumulated reference during the imposition of a period of continuous water stress.

\section{REFERENCES}

AGRIANUAL 2010. Anuário estatístico da agricultura. São Paulo: FNP Consultoria e Comércio, 2010. p. 239-242.

BONATO, C. M. Homeopatia em modelos vegetais. Cultura Homeopática, São Paulo, v.21, p.2428, 2007.

CARR, M. K. V.; KNOX, J. W. The water relations and irrigation requirements of sugar-cane (Saccharum officinarum): A review. Experimental Agriculture, Cambridge, v.47, p.1-25, 2011.

COSTA, C. T. S.; FERREIRA, V. M.; ENDRES, L.; FERREIRA, D. T. R. G.; GONÇALVES, E. R. Crescimento e produtividade de quatro variedades de cana-de-açúcar no quarto ciclo de cultivo. Revista Caatinga, Mossoró, v. 24, p. 56-63, 2011.

DALRI, A.B.; CRUZ, R.L. Produtividade da cana-de-açúcar fertirrigada com N e K via gotejamento subsuperficial. Engenharia Agrícola, Jaboticabal, v.28, n.3, 2008. Disponível em: < http://www.scielo.br/scielo.php?script=sci_arttext\&pid=S0100-

69162008000300012\&lng=pt\&nrm=iso $>$. Acesso em: 8 jan. 2011.

EFEOĞLU, B.; EKMEKÇI, Y.; ÇIÇEK, N. Physiological responses of three maize cultivars to drought stress and recovery. South African Journal of Botany, Pretoria, v.75, p.34-42, 2009.

IEA - Instituto de Economia Agrícola. Cana-de-açúcar para indústria: o quanto vai precisar

INMAN-BAMBER, N.G. Sugar-cane water stress criteria for irrigation and drying off. Field Crops Research. Amsterdam, v.89, p. 107-122, 2004.

INMAN-BAMBER, N. G.; SMITH, D. M. Water relations in sugar-cane and response to water deficits. Field Crops Research, Amsterdam, v. 92, p.185-202, 2005.

crescer. Disponível em: <www.iea.sp.gov.br/out/verTexto.php?codTexto=7448>. Acesso em: 17 set. 2012.

MACHADO, R. S.; RIBEIRO, R. V.; MARCHIORI, P. E. R.; MACHADO, D. F. S. P.;

MACHADO, E. C.; LANDELL, M. G. de A. Respostas biométricas e fisiológicas ao déficit hídrico em cana-de-açúcar em diferentes fases fenológicas. Pesquisa Agropecuária Brasileira, Brasília, v.44, n.12, p. 1575-1582, dez. 2009.

ROSENFELD, U.; LEME, F. J. A. Produtividade da cana-de-açúcar irrigada por aspersão: estudo de épocas de irrigação. In: CONGRESSO NACIONAL DA SOCIEDADE DOS TÉCNICOS AÇUCAREIRO E ALCOOLEIROS DO BRASIL, 3., 1984, São Paulo. Proceedings... São Paulo: STAB, 1984. p.18.

SMIT, M.A.; SINGELS, A. The response of surgarcane canopy development to water stress. Field Crops Research, Cambridge, v. 98, p. 91-97, 2006.

THORNTHWAITE, C.W.; MATHER, J.R. The water balance. Publications in Climatology. New Jersey: Drexel Inst. of Technology, 1955. 104 p. 